\title{
Prawne aspekty położenia mniejszości narodowych na Górnym Śląsku w latach 1918-1939
}

Burzliwe dzieje Górnego Śląska po I wojnie światowej - spowodowane przede wszystkim wybuchem trzech powstań ludności polskiej i przeprowadzeniem na tym obszarze plebiscytu, wpisujące się zresztą w pogmatwane losy niemal całej Europy w tamtym okresie - w skomplikowany sposób wpłynęły na położenie jego niemieckich i polskich mieszkańców. Podział Górnego Śląska w wyniku tych wydarzeń na większą część, należącą do Rzeszy Niemieckiej, i mniejszą część, znajdującą się w granicach Rzeczpospolitej Polskiej, stał się w całym okresie międzywojennym zarzewiem licznych lokalnych konfliktów narodowościowych, politycznych i społecznych ${ }^{1}$. Konieczność rozwiązywania nieustannie pojawiających się w relacjach polskoniemieckich na tym obszarze rozmaitych kwestii spornych oraz łagodzenia wywoływanych przez nie następstw wymagała podjęcia stosownych regulacji prawnych wspólnie przez władze obydwu państw. Nie było to bynajmniej ani łatwe, ani proste zadanie. Stosunki między Polską i tzw. Republiką Weimarską nie układały się bowiem dobrze po I wojnie światowej, a zwłaszcza w pierwszych latach po jej zakończeniu, gdy oba państwa dotkliwie odczuwały skutki światowego kryzysu kapitalizmu. Na raczej złe relacje bilateralne miały również wpływ czynniki i okoliczności polityczne ${ }^{2}$. Najważniejszymi spośród nich były silne tendencje nacjonalistyczne i odwetowe w ówczesnych

1 Spośród już obszernej literatury naukowej na ten temat, powstałej tak w Polsce, jak i w Niemczech, nierzadko obciążonej brakiem obiektywizmu poznawczego, pozytywnie wyróżniają się niektóre bardziej współczesne publikacje, w tym wspólne dzieło polskich i niemieckich autorów Historia Górnego Ślaska. Polityka, gospodarka i kultura europejskiego regionu, pod red. J. Bahlckego, D. Gawreckiego i R. Kaczmarka, Gliwice 2011. Mniej pod tym względem obiektywne, choć źródłowo dobrze udokumentowane wydaje się opracowanie Oberschlesien nach dem Ersten Weltkrieg. Studien zu einem nationalen Konflikt und seiner Erinnerung, hrsg. von K. Struve, Marburg 2003. Por. też M. Czapliński, Historia Ślaska, Wrocław 2002; J. Drabina, Górny Śląsk, Wrocław 2002.

${ }^{2}$ Szerzej o tym por. J. Krasuski, Stosunki polsko-niemieckie 1919-1932, Poznań 1975, passim. 
Niemczech, które występowały tak w szerokich grupach społeczeństwa, jak i w kręgach tamtejszej władzy. Z kolei w Polsce niemałe były obawy przed niemieckim nacjonalizmem i rewizjonizmem oraz ewentualnym brakiem lojalności ze strony Niemców nadal mieszkających na terenach należących do 1918 r. do Rzeszy. Niekiedy owo poczucie zagrożenia i niepewności (nie tylko w odniesieniu do mniejszości niemieckiej, ale także innych mniejszości narodowych) prowadziło do stosowania polityki odgórnej polonizacji narodowo obcych mieszkańców obszarów uzyskanych po I wojnie światowej. Wszystko to niewątpliwie powodowało piętrzenie się wielu trudności związanych z regulacją sytuacji politycznej i prawnej na Górnym Śląsku.

Jak już wspomniałem, skomplikowana sytuacja narodowościowa na tym podzielonym między dwa państwa obszarze po zakończeniu I wojny światowej wymagała podjęcia stosownych regulacji prawno-międzynarodowych. $\mathrm{Na}$ początku XX w. nie została jeszcze szeroko wypracowana ani teoria, ani tym bardziej praktyka odnosząca się do prawnych sposobów traktowania mniejszości narodowych. Samo zresztą pojęcie „mniejszość narodowa” zostało po raz pierwszy użyte stosunkowo późno, bo prawdopodobnie dopiero w latach 30. XIX w. - na fali budzenia się w ówczesnej Europie poczucia świadomości narodowej, które doprowadziło (m.in. na ziemiach polskich) do wybuchu powstań narodowych i walk narodowowyzwoleńczych (m.in. Włoszech) ${ }^{3}$. To właśnie wtedy zaczęły się kształtować zręby przyszłej doktryny politycznej i prawnej dotyczącej mniejszości narodowych, związane z rozwojem już w XVIII stuleciu liberalnych koncepcji praw człowieka, które za sprawą konstytucji USA z 1787 r., a następnie francuskiej Deklaracji Praw Człowieka i Obywatela z 1789 r. stały się z czasem jednym z fundamentów demokratycznych ustrojów politycznych. Spory wkład w powstanie teorii mniejszości narodowych wniósł $\mathrm{w}$ drugiej połowie XIX stulecia wybitny prawnik i polityk włoski, zaangażowany w działalność na rzecz zjednoczenia Italii - Pascale Stanislao Mancini. Opowiadał się on za równym traktowaniem wszystkich mieszkańców danego państwa niezależnie od ich narodowości. Mancini uważał bowiem narodowość za cechę pierwotną i ważniejszą od przynależności państwowej (która mogła się zmieniać), gdyż ukształtowaną w wyniku długotrwałych procesów dziejowych (na które składały się tradycja, kultura, obyczaje i język) i z tego powodu zasługującą - jako grupa posiadająca prawa wcześniej nabyte - na szczególną ochronę ${ }^{4}$. Do rozwoju rzeczonych koncepcji przyczynił się również jeden z twórców doktryny pozytywizmu prawni-

${ }^{3}$ Bodaj najwcześniej owo pojęcie zostało zdefiniowane w 1835 r. w „Słowniku Akademii Francuskiej”. K. Jonca, Status prawny mniejszości na obszarze podzielonego Górnego Śląska w latach 1922-1939, (w:) Górny Śląsk po podziale w 1922 roku. Co Polska, a co Niemcy dały mieszkańcom tej ziemi?, pod red. Z. Kapały, W. Lesiuka i M.W. Wanatowicz, t. II, Bytom 1997, s. 19.

${ }^{4}$ Por. M. Malatesta, Society and the Professions in Italy, 1860-1914, Cambridge 2002, s. 79 $\mathrm{i}$ in. 
czego w Niemczech - Georg Jellinek. Pod koniec XIX w. wyłożył on ciekawą koncepcję uniwersalnych i ponadczasowych praw ludzkich i obywatelskich, na której oparł swoje poglądy na temat praw przynależnych mniejszościom narodowym ${ }^{5}$. Jeszcze do końca tamtego stulecia $\mathrm{w}$ zasadzie żaden wpływowy polityk nie stosował się jednak do wskazanych założeń rodzącej się teorii narodowości. W ówczesnej Europie powszechne było wtedy w kręgach władz poszczególnych państw (zwłaszcza ówczesnych mocarstw) przekonanie o braku podstaw do uznania jeszcze innych niż powszechnie obowiązujące praw przysługujących grupom narodowym. Co więcej: z racji swej odrębności mniejszości bywały one nawet dyskryminowane, a w każdym razie uważane za niezasługujące na szczególną ochronę prawną. Od mniejszości narodowych, nota bene na ogół oficjalnie nie określanych tym mianem, oczekiwano natomiast zachowania lojalności wobec władz zamieszkiwanego przez nie państwa poprzez pełne podporządkowanie się obowiązującemu w nim prawu i niewysuwanie zbiorowych roszczeń.

Wymienione teorie narodowości, stopniowo uwzględniające rozmaite potrzeby i aspiracje grup narodowych, mogły doczekać się przynajmniej częściowej realizacji dopiero po I wojnie światowej, kiedy rozpadowi uległy wielonarodowe imperia Habsburgów, Hohenzollernów i Romanowów. Na gruzach tych mocarstw wyrosły nowe państwa, które również nie były - jak np. Polska - jednorodne etnicznie. Poglądy Manciniego starał się wtedy wcielić w życie prezydent USA Thomas Woodrow Wilson, głosząc koncepcję samostanowienia narodów i związaną z nią teorię państwa narodowego. Opierała się ona na zasadzie, by „każdy świadomy swej odrębności naród stanowił niepodległe państwo, każde zaś państwo było oddzielnym organizmem narodowym" ". Sprawą ochrony praw mniejszości narodowych w państwach istniejących do $1918 \mathrm{r}$. i powstałych w Europie po zakończeniu I wojny światowej zajęła się pokojowa konferencja obradująca w Paryżu w pierwszej połowie 1919 r. Na podstawie art. 93 zawartego 28 VI tegoż roku traktatu pokojowego w tym samym dniu przyjęto w Wersalu także traktat między byłymi państwami ententy i Polską o ochronie ludności niemieckiej na obszarach odstąpionych Rzeczypospolitej ${ }^{7}$. Nie doszło natomiast na paryskiej konferencji do zawarcia traktatu z Rzeszą w sprawie ochrony polskiej mniejszości. Przedstawiciele mocarstw sprzymierzonych i stowarzyszonych nie uznali bowiem wszystkich racji polskiej delegacji w Wersalu, domagającej się równego traktowania mniejszości w Polsce i Niemczech. Nieprzychylne Polsce stanowisko reprezentantów byłej ententy zebranych w Wersalu spowodowało

${ }^{5}$ G. Jellinek, Erklärung der Menschen-und Bürgerrechte, b.m.w. 1895; idem, Das Recht der Minoritäten, b.m.w. 1898. Por. też M. Maciejewski, U źródet liberalnej koncepcji praw człowieka i obywatela, „Przegląd Prawa i Administracji”, t. LXIII, 2004, s. 7 i n.

${ }^{6}$ B. Bouffał, Ochrona mniejszości w prawie narodów, Warszawa 1928, s. XVIII.

${ }^{7}$ Traktat został ogłoszony dopiero 6 XII 1920 r. Dz. U. RP 1920, nr 110, poz. 728. 
krytykę m.in. ze strony Ignacego Paderewskiego. Na konferencji pokojowej apelował on do władz francuskich, brytyjskich i amerykańskich, by zapewniły Polakom mieszkającym w Rzeszy możliwość korzystania „z tych samych praw i przywilejów co do języka i urządzeń, jakie przyznane zostają ludności niemieckiej, zaliczonej na mocy traktatu w poczet obywateli polskich" ${ }^{8}$. Już 16 VI 1919 r. sprzymierzeni przychylnie ustosunkowali się natomiast do postulatu delegacji niemieckiej, równocześnie zapewniając - bez podjęcia jednak stosownych zobowiązań na gruncie prawa międzynarodowego - o takim samym traktowaniu mniejszości w Rzeszy. Dodam, że już w tamtym okresie i w latach późniejszych pojawiały się w Niemczech głosy oskarżające Polskę o nieuznawanie praw mniejszości niemieckiej. $Z$ takim twierdzeniem wystąpił w 1927 r. Hermann Plettner, formułując swój pogląd na podstawie skądinąd błędnej analizy polskiej ustawy o obywatelstwie (1920) i rozporządzenia regulującego sprawy opcji $(1920)^{9}$. Z tego rodzaju oskarżeniami polemizował młody naukowiec Jerzy Kostanecki w obronionej - co ważne - na uniwersytecie w Kolonii rozprawie doktorskiej. Przedstawił on w niej prawne argumenty wskazujące na respektowanie przez Polskę praw mniejszości niemieckiej na Górnym Śląsku ${ }^{10}$. Krytyka przez Niemcy rzekomo krzywdzącej mniejszość niemiecką polityki władz Rzeczypospolitej zapewne wpisywała się w szeroki nurt antypolskiej propagandy uprawianej w Republice Weimarskiej. Nadmienię, że jej ostrze wymierzone było w ogóle w istnienie państwa polskiego ${ }^{11}$.

Postanowienia traktatu z Polską dotyczącego mniejszości narodowych wywoływały jeszcze inne krytyczne opinie oraz wątpliwości i kontrowersje ze strony polskiej delegacji na konferencję paryską i przedstawicieli nauki prawa w naszym kraju. Za niefortunne uznane zostało sformułowanie art. 12 tego traktatu - będącego zresztą wzorem dla innych traktatów pokojowych i w sprawach mniejszości ${ }^{12}$ - ujmującego postanowienia dotyczące osób na-

${ }^{8}$ Sprawy polskie na Konferencji Pokojowej w Paryżu w 1919 r. Dokumenty i materiaty, pod red. R. Bierzanka i J. Kukułki, t. 3, Warszawa 1968, s. 318. Podobnie argumentował K. Openkowski w artykule Das geltende Recht der nationalen Minderheiten in Deutschland, „Kulturwehr. Organ des Verbandes der nationalen Minderheiten in Deutschland”, H. 3, Berlin 1926, s. 110.

${ }^{9}$ H. Plettner, Das Problem des Schutzes nationaler Minderheiten, Leipzig 1927, s. 89 i in. Por. bardziej wyważone pod tym względem opinie innego autora niemieckiego - F. Heidelcka, Die Stellung der Deutschstums in Polen, „Deutsche Blätter in Polen”, 1929, H. 2, s. 25 i n.

${ }^{10}$ J. Kostenecki, Ochrona mniejszości narodowych na Górnym Śląsku w świetle polsko-niemieckiej Konwencji Górnośląskiej z 15 maja 1922 r., (w:) J. Kokot, Przypomnienie aktualnej pracy Jerzego Kosteneckiego o Górnośląskiej Konwencji Genewskiej z 1922 roku, „Przegląd Stosunków Międzynarodowych", nr 3/4, Opole 1974, s. 219 i n.

${ }^{11}$ Por. J. Sobczak, Propaganda zagraniczna Niemiec weimarskich wobec Polski, Poznań 1973, passim; K. Fiedor, Antypolskie organizacje w Niemczech (1918-1939), Wrocław 1973, passim; idem, Bund Deutscher Osten w systemie antypolskiej propagandy, Warszawa 1977, passim.

${ }^{12}$ Chodziło m.in. o traktaty z Czechosłowacją, Austrią, Bułgarią, Rumunią, Węgrami i Jugosławią zawarte w latach 1919-1923. Niektóre z nich nie weszły jednak nigdy w życie, jak np. traktat między Polską a Czechosłowacją czy między Polską Estonią, Łotwą i Finlandią. 
leżących do mniejszości narodowej w kategorii „zobowiązania o znaczeniu międzynarodowym", co w konsekwencji oznaczało poddanie tych przepisów późniejszym gwarancjom Ligii Narodów. Warto zaznaczyć, że przyjęte przez tę organizację rozwiązania w omawianej dziedzinie odznaczały się brakiem terminologicznej precyzji. Zamiast pojęcia „mniejszość narodowa” z reguły posługiwano się bardziej enigmatycznym i mającym mniejszą wymowę prawną określeniem „mniejszość językowa”, „mniejszość religijna” czy „mniejszość rasowa”. Członkowie Ligi Narodów kierowali się bowiem zasadą, według której „w państwie z prawnego punktu widzenia może być tylko jeden naród"13. Gwarancji przewidzianych przez tę organizację wobec Niemców w Polsce nie uzyskały natomiast mniejszości narodowe w Niemczech, mimo że podejmowały w tym celu odpowiednie zabiegi. Jedyną prawną ochronę praw tych grup stanowiła wówczas konstytucja Rzeszy z 11 VIII 1919 r. (art. 113) czy konstytucja Prus z 30 XI 1920 r. (art. 73). Nic też dziwnego, że wybitny polski prawnik Stanisław Kutrzeba uznał w 1923 r. traktat wielkich mocarstw z Rzecząpospolitą w sprawie mniejszości niemieckiej za „podstawowe jednostronnie narzucone Polsce ograniczenie suwerenności”14. W podobnym tonie wypowiadali się również inni polscy prawnicy. Jednym z nich był Kazimierz Kierski, według którego traktat o ochronie mniejszości niemieckiej stanowił przejaw „lekceważenia” i „skrzywdzenia” Polski przez byłe państwa ententy ${ }^{15}$. Na dysproporcje w sposobie prawnego traktowania mniejszości niemieckiej w Polsce i polskiej w Niemczech zwracali także uwagę niektórzy ówcześni uczeni zagraniczni. Zrozumienie dla krytycznego wobec polityki wielkich mocarstw stanowiska władz polskich w tej sprawie wyraził pod koniec lat 20. XX w. profesor paryskiej École des Sciences Politiques - Charles Dupuis ${ }^{16}$.

Po przeprowadzonym w marcu 1921 r., zapowiadanym już w traktacie wersalskim plebiscycie na Górnym Śląsku, doszło do podjęcia z inicjatywy rządu francuskiego przez organ wykonawczy państw sprzymierzonych i stowarzyszonych - Radę Ambasadorów - dalekosiężnej decyzji o podziale tego obszaru między Niemcy i Polskę. Choć nie satysfakcjonowała ona żadnej

${ }^{13}$ K. Jonca, Status prawny mniejszości..., s. 22. W sprawie zasad funkcjonowania tej organizacji i sposobów realizacji jej zadań odsyłam do monografii S. Sierpowskiego, Liga Narodów w latach 1919-1926, Wrocław 2005.

${ }^{14}$ S. Kutrzeba, Polskie prawo polityczne wedlug traktatów, cz. 2: Gdańsk-Górny Śląsk, Kraków 1923, s. 6 i in.

${ }^{15}$ K. Kierski, Ochrona praw mniejszości w Polsce, Poznań 1933, s. 76.

${ }^{16}$ C. Dupuis, Ochrona mniejszości rasowych, językowych i religijnych, „Przegląd Polityczny”, t. 10, z. 4/5 Warszawa 1929, s. 163 i n. Także ten uczony krytycznie oceniał brak terminologicznej precyzji ze strony Ligi Narodów w odniesieniu do mniejszości narodowych. Ibidem, s. 165. 
z obu stron państwowych, stała się faktem rodzącym wiele skutków, m.in. w sferze prawa międzynarodowego. Rada Ambasadorów zobowiązała bowiem Polskę i Rzeszę do zawarcia porozumienia dotyczącego prawnej regulacji kwestii narodowościowych na objętym plebiscytem obszarze ${ }^{17}$. Polskoniemieckie rokowania $\mathrm{w}$ tej sprawie rozpoczęły się niebawem po zapadnięciu rzeczonej decyzji wielkich mocarstw, tj. w listopadzie 1921 r. i odbywały się w siedzibie Ligi Narodów w Genewie pod przewodnictwem byłego prezydenta Konfederacji Szwajcarskiej Felixa Calondera. Prace nad przygotowaniem traktatu odnoszącego się do mniejszości narodowych przebiegały na tyle sprawnie, choć nie bez pewnych perturbacji, że był on gotowy już w maju 1922 r. Ratyfikowana na początku czerwca tegoż roku konwencja górnośląska - bo ostatecznie taką właśnie formę prawną przybrał ten dokument - weszła w życie w połowie tego samego miesiąca ${ }^{18}$. Mająca obowiązywać piętnaście lat od momentu faktycznego podziału Górnego Śląska (do 1937 r.) konwencja była - w opinii Władysława Zaleskiego - jedną z „najbardziej interesujących, a zarazem najśmielszych i najdalej idących prób w kierunku stworzenia międzynarodowego prawa mniejszościowego i uprawnień mniejszości w ogóle"19. Już w tym miejscu należy jednak podkreślić, że konwencja wyraźnie nie definiowała pojęcia „mniejszość narodowa”, co stało się - o czym będzie mowa w dalszej części artykułu - przyczyną rozmaitych wątpliwości, a nawet nieporozumień między niemieckimi i polskimi prawnikami interpretującymi jej postanowienia. Co się jeszcze ogólnie tyczy tego dokumentu: był on jednym z najbardziej wówczas obszernych traktatów dotyczących stosunków międzynarodowych. Konwencja z 15 V 1922 r. liczyła bowiem ponad sześćset artykułów, podczas gdy traktat odnoszący się do mniejszości niemieckiej w Polsce z 1919 r. składał się jedynie z niecałych czterystu pięćdziesięciu artykułów. W odróżnieniu od tego traktatu konwencja górnośląska - określana także jako konwencja genewska - regulowała status prawny nie tylko ludności niemieckiej w należącej do Rzeczypospolitej części tego obszaru plebiscytowego, ale również sytuację prawną polskiej mniejszości w części Górnego Śląska znajdującej się w granicach Rzeszy. Wskutek tego odpadły wcześniejsze przesłanki (występujące w traktacie w sprawie mniejszości z 28 VI 1919 r.)

${ }^{17} \mathrm{Z}$ nowszej literatury na ten temat por. K. Eichner, Briten, Französen und Italiener in Oberschlesien 1920-1922. Die Interallierteregierungs- und Plebiszitkommission in Spiegel der britischen Akten, St. Katharinen 2002.

${ }^{18}$ Pełnomocnikiem rządu polskiego do negocjacji z władzami Niemiec w sprawie tej konwencji był min. K. Olszowski, a pełnomocnikiem władz Rzeszy - min. E. Schiffer. W zespole doradców, pracujących w jedenastu podkomisjach, znaleźli się m.in. P. Geisenheimer, A. Pistorius i G. Williger. Szerzej o tym por. K. Jonca, Polityka narodowościowa Trzeciej Rzeszy na Ślasku Opolskim 1933-1940. Studium polityczno-prawne, Katowice 1970, s. 35 i n. Odsyłam też do opracowania zbiorowego Podziat Ślaska w 1922 r. Okoliczności i następstwa, pod red. A. Brożka i T. Kulak, Warszawa 1996, s. 7 i n.

${ }^{19}$ W. Zaleski, Międzynarodowa ochrona mniejszości, Warszawa 1932, s. 97. 
nierównego traktowania w sensie prawnym obu mniejszości narodowych. Przyjęcie takiego rozwiązania prawnego oznaczało odejście przez Radę Ambasadorów - z korzyścią dla interesów Polski - od zasad polityki wobec obu mniejszości stosowanych przez byłe państwa ententy na paryskiej konferencji pokojowej w 1919 r. Władze Rzeczypospolitej mogły zatem ratyfikację konwencji górnośląskiej poczytać za sukces swej dyplomacji - tym większy, że jeszcze w 1920 r. ważyły się przecież losy młodej polskiej niepodległości, zagrożonej przez wojnę z bolszewikami, którym faktycznie sprzyjały władze niemieckie. Należy przy tym zauważyć, że postanowienia konwencji w żadnym przypadku nie dyskryminowały strony niemieckiej, choć nie były dla niej w pełni satysfakcjonujące. Niewątpliwie władzom Rzeszy bardziej odpowiadały regulacje prawne przyjęte $\mathrm{w}$ traktacie dotyczącym mniejszości niemieckiej z końca czerwca 1919 r. Nota bene strona polska przyjęła na siebie $\mathrm{w}$ omawianej konwencji wszystkie zobowiązania wynikające $\mathrm{z}$ tego traktatu.

Konwencja górnośląska z 15 V 1922 r. składała się z sześciu głównych części. W kolejności regulowała sprawy ustawodawstwa, ochrony praw nabytych, wywłaszczenia, obywatelstwa i zamieszkania, ochrony mniejszości, kwestii socjalnych i gospodarczych oraz instytucji mających czuwać nad przestrzeganiem norm tego traktatu (Górnośląska Komisja Mieszana i Górnośląski Trybunał Rozjemczy $)^{20}$. Już we wstępie konwencji za jej podstawowy cel uznano - prócz ustanowienia na Górnym Śląsku ustroju prawnego zgodnego z postanowieniami Konferencji Ambasadorów z października 1921 r. - ochronę mniejszości narodowych. W związku z tym władze Rzeczypospolitej zobowiązywały się do zachowania na przyznanym Polsce obszarze Górnego Śląska na okres piętnastu lat prawa materialnego, które obowiązywało na tym terytorium do czasu zmiany suwerenności państwowej, w szczególności przepisów dotyczących górnictwa, przemysłu i handlu oraz norm prawa pracy. Nie oznaczało to jednak braku możliwości zastąpienia owego prawa ,innymi postanowieniami mogącymi być zastosowanymi" na całym obszarze Polski ${ }^{21}$. W dość elastyczny sposób uregulowano także kwestię obywatelstwa. W myśl art. 25 konwencji obywatele niemieccy mieszkający w polskiej części Górnego Śląska stawali się z mocy prawa obywatelami Rzeczypospolitej, co wszakże nie wykluczało prawa opcji ,na rzecz obywatelstwa niemieckiego w przeciągu dwóch lat od chwili zmiany suwerenności”. W tym samym okresie optować

${ }^{20}$ Dz. U RP 1922, nr 44, poz. 370. W sprawie regulacji przyjętych w konwencji i zasad realizacji jej postanowień odsyłam do prac M. Korowicza, Górnośląska ochrona mniejszości 1922-1937 na tle stosunków narodowościowych, Katowice 1938; S. Rogowskiego, Komisja Mieszana dla Górnego Śląsa (1922-1937), Opole 1977.

${ }^{21}$ Przed licznymi problemami prawnymi związanymi ze stosowaniem norm prawa wewnętrznego i międzynarodowego stanął aparat wymiaru sprawiedliwości. Zagadnienie to nie doczekało się jeszcze pełnego opracowania naukowego. Tylko częściowo lukę w tej dziedzinie wypełnia monografia L. Krzyżanowskiego, Sędziowie w II Rzeczypospolitej. Okręgi apelacyjne: krakowski i katowicki, Katowice 2011. 
na rzecz obywatelstwa polskiego mogli również Polacy - obywatele niemieccy, o ile w momencie państwowego podziału Górnego Śląska mieli ukończone osiemnaście lat. W konwencji posłużono się znamienną interpretacją pojęcia obywateli niemieckich będących Polakami. Za takich uznani zostali bowiem ci obywatele niemieccy, którzy do 1 VIII 1921 r. „okazali swym zachowaniem, że poczuwają się do polskości" ${ }^{22}$. W ten sposób starano się z jednej strony docenić zwłaszcza działalność powstańców śląskich w latach 1919-1921, co oczywiście musiało budzić sprzeciw rządu Rzeszy; z drugiej zaś - utrudnić możliwość wydalania z obszaru Niemiec osób należących do mniejszości językowej, rasowej czy religijnej z tych lub innych powodów „niewygodnych” dla władz państwowych ${ }^{23}$. Przed skutkami ewentualnej samowoli lub arbitralności w tej dziedzinie miały zabezpieczać gwarancje przestrzegania konwencji górnośląskiej udzielone przez Ligę Narodów. Tytuł I w części III konwencji wyraźnie ujmował bowiem zawarte w niej postanowienia jako zobowiązania prawno-międzynarodowe wiążące Polskę i Niemcy.

Szczególnego znaczenia $\mathrm{w}$ odniesieniu do mniejszości narodowych polskiej i niemieckiej na Górnym Śląsku - nabierały zawarte w art. 64-68 „prawa zasadnicze”, które miały stanowić fundament szczegółowych regulacji prawnych dotyczących położenia ludności na tym obszarze. Do tych naczelnych praw zaliczono prawa cywilne i polityczne oraz całkowitą ochronę życia i wolności. W celu podkreślenia znaczenia praw zasadniczych zastrzeżono w konwencji, że żadna ustawa, rozporządzenie lub czynność prawna nie mogą pozostawać w sprzeczności z tymi prawami. Przyjęcie przez twórców konwencji takiego stanowiska oznaczało zastosowanie w rzeczonych kwestiach ważnego założenia prymatu nad prawem wewnętrznym regulacji prawno-międzynarodowych, co dostrzeżono i w niemieckim, i w polskim międzywojennym piśmiennictwie prawniczym ${ }^{24}$. Należy podkreślić, że za podstawę owych naczelnych praw uznano zasadę równego traktowania nie tylko obu mniejszości narodowych, ale w ogóle wszystkich mieszkańców tego obszaru (a więc np. również Żydów) bez względu na urodzenie, język, religię czy rasę. Kolejne artykuły konwencji precyzowały przejawy owej równości w po-

${ }^{22}$ Art. 27 par. 1-3. Postanowienie to odnosiło się także do Polaków-obywateli Niemiec, zamieszkałych w Rzeszy w momencie państwowego podziału Górnego Śląska, poza częścią niemiecką obszaru plebiscytowego, jeśli oni lub ich rodzice urodzili się na tym obszarze. K. Jonca, Status prawny mniejszości..., s. 25.

${ }^{23}$ Władze niemieckie niejednokrotnie dostarczały dowodów na dążenie do ograniczania praw mniejszości polskiej na obszarze plebiscytowym, co było powodem licznych skarg ze strony ludności polskiej. Por. F. Połomski, Niemiecki Urząd do Spraw Mniejszości (1922-1937), Wrocław 1965, s. 79 i n.; G. Hitze, Carl Ulitzka (1873-1953) oder Oberschlesien zwischen den Weltkriegen, Düsseldorf 2002, s. 34 i n.

${ }^{24}$ Odsyłam do już powołanej polskiej literatury oraz m.in. do artykułu E. Loewenfelda, Der Rechtsschutz der Minoritäten vor dem Völkerbunde, „Juristische Wochenschrift”, 1924, H. 17-18, s. 1298. 
szczególnych dziedzinach życia publicznego, wymieniając w tym kontekście prawo piastowania rozmaitych urzędów i funkcji oraz wykonywania zawodów, nadawania odznaczeń i dyplomów. W art. 78 i 79 przewidziane zostało ponadto prawo członków mniejszości narodowych i innych mieszkańców podzielonego Górnego Śląska do stowarzyszania się i zgromadzania oraz publikowania we własnym języku. Wszyscy mieszkańcy tego obszaru uzyskali także - na mocy konwencji (art. 76) - prawo udziału w wyborach do organów reprezentacyjnych instytucji społecznych i zgromadzeń kościelnych. Co się zaś tyczy udziału w wyborach do organów państwowych lub samorządowych, to ze zrozumiałych względów prawo takie przysługiwało jedynie osobom będącym obywatelami Polski bądź Niemiec ${ }^{25}$. W tym przypadku przeważyła zasada lojalności wobec władz państwa, na obszarze którego zamieszkuje dana osoba, a nie sama idea ochrony praw mniejszościowych. Twórcy konwencji wyszli bowiem z następującego założenia: jeśli np. Niemiec mieszkający w polskiej części Górnego Śląska chce nadal być obywatelem Rzeszy, to znaczy, że świadomie rezygnuje z możliwości rozstrzygania w wyborach do władz przedstawicielskich o sprawach państwa polskiego ${ }^{26}$. Przegląd postanowień konwencji górnośląskiej nie byłby pełny, gdyby zabrakło w nim wywodów dotyczących jej innych postanowień. W konwencji sporo miejsca zajęły zatem regulacje odnoszące się w kolejności spraw religii, szkolnictwa i języka. Nie sposób omówić wszystkich, nierzadko nader szczegółowych regulacji w tych dziedzinach. Ograniczę się zatem do wskazania - w moim przekonaniu - najważniejszych spośród nich.

Górnośląska konwencja gwarantowała wszystkim mieszkańcom byłego obszaru plebiscytowego prawo swobodnego wykonywania - prywatnie i publicznie - „praktyk każdego wyznania, religii lub wiary” (art. 85). Warunkiem realizacji praw w tej dziedzinie była jednak zgodność owych praktyk z porządkiem publicznym i dobrymi obyczajami, a zatem m.in. nienarzucanie nikomu obowiązku stosowania się do nich lub nieprzeszkadzanie w głoszeniu kultu religijnego. Z prawem do swobód religijnych wiązało się, również zagwarantowane w konwencji, prawo do samodzielnego mianowania i ustanawiania własnych duchownych, zakonników, urzędników kościelnych i personelu pomocniczego ${ }^{27}$. Wszystkim mieszkańcom obszaru objętego konwencją zapewniano możliwość obchodzenia własnych świąt i uroczystości religijnych. Ochrona praw mniejszości narodowych wyrażała się również w posta-

${ }^{25} \mathrm{~W}$ ten sposób interpretowali postanowienia konwencji polscy autorzy międzywojenni, w tym S. Kutrzeba (Polskie prawo polityczne..., s. 187) i K. Kierski (op. cit., s. 240). Odsyłam też do pracy J. Ogonowskiego, Uprawnienia językowe mniejszości narodowych w Rzeczypospolitej Polskiej 1918-1939, Warszawa 2000, s. 42 i n.

${ }^{26}$ K. Jonca, Status prawny mniejszości..., s. 26.

${ }^{27} \mathrm{O}$ praktycznych aspektach uregulowań w sprawach religijnych zawartych w konwencji por. monografię L. Krzyżanowskiego, Kościół katolicki wobec mniejszości niemieckiej na Górnym Ślasku w latach 1922-1930, Katowice 2000, passim. 
nowieniu nakazującym równe traktowanie czynionych przez nie zabiegów o wsparcie działalności religijnej lub kościelnej z publicznych lub komunalnych budżetów. Warto dodać, że z realizacją tych postanowień w praktyce bywało różnie. Rozmaite przeszkody na drodze do urzeczywistnienia praw mniejszościowych częściej piętrzyły władze niemieckie niż polskie. Podobnie bywało w przypadku praw mniejszości odnoszących się spraw szkolnych ${ }^{28}$. Nie lepiej przedstawiała się kwestia przestrzegania, zwłaszcza na niemieckim Górnym Śląsku, postanowień konwencji dotyczących prawa do używania języka ojczystego. W omawianym dokumencie przyjęto generalną zasadę swobody posługiwania się tym językiem we wszystkich działach życia prywatnego i publicznego (art. 134). Każdy mieszkaniec byłego obszaru plebiscytowego miał prawo zwracać się do władz cywilnych w języku ojczystym. Odpowiedź na jego pismo powinna być natomiast sporządzona w języku urzędowym z dołączonym do niej tłumaczeniem na język ojczysty petenta (art. $135)^{29}$. Ponadto w języku mniejszości narodowych miały odbywać się zajęcia lekcyjne w szkołach przeznaczonych dla tej ludności. Na polskim obszarze poplebiscytowym nauczyciele powinni być jednak obywatelami Rzeczypospolitej, a na obszarze niemieckim - obywatelami Rzeszy. Warto nadmienić, że wbrew niekiedy formułowanym przez stronę niemiecką zastrzeżeniom ${ }^{30}$, ze wskazanymi regulacjami prawno-międzynarodowymi nie pozostawały W sprzeczności przepisy tzw. ustawy śląskiej z 16 I 1923 r. zawierającej postanowienia dotyczące używania języka polskiego dla władz i urzędów. Na jej podstawie wyłącznie w języku polskim należało na obszarze Górnego Śląska znajdującym się w granicach Rzeczypospolitej wystawiać dokumenty publiczne. W tym też języku powinno się pisać nazwy miejscowości czy ulic ${ }^{31}$. Jak choćby wynika tylko $\mathrm{z}$ omówionych, niektórych postanowień konwencji genewskiej, zakres praw przysługujących mniejszościom narodowym był rozległy i w zasadzie kompleksowy. W przypadku naruszenia tych uprawnień przysługiwały rozmaite środki zabezpieczające i odwoławcze, w tym skargi do Urzędu do Spraw Mniejszości działającego na polskim (Katowice) i niemieckim (Opole) obszarze poplebiscytowym.

${ }^{28}$ Konwencja szczegółowo regulowała wszystkie typy i rodzaje szkolnictwa w odniesieniu do mniejszości narodowych, pomijając jednak kwestię tworzenia szkół zawodowych, co stanowiło istotne uchybienie ze strony twórców tego dokumentu. K. Jonca, Polityka narodowościowa Trzeciej Rzeszy..., s. 203 i n.

${ }^{29}$ Szerzej J. Ogonowski, op. cit., s. 45 i n. Odsyłam też do pracy A. Chojnowskiego, Koncepcje polityki narodowościowej rządów polskich w latach 1921-1939, Wrocław 1979, s. 29 i n.

${ }^{30}$ Por. m.in. J. Fischer, Das Recht und der Schutz der polnischen Minderheit in Oberschlesien, Berlin 1931; J. Robinson, Das Minoritätenproblem und seine Literatur, Berlin-Leipzig 1928; J.P. Warderholt, Das Minderheitenrecht in Oberschlesien, Berlin 1930.

${ }^{31}$ Rzeczona ustawa zawierała także przepisy przejściowe (obowiązujące do 15 V 1926 r.) dotyczące posługiwania się językiem polskim przez urzędników, notariuszy czy adwokatów. S. Kutrzeba, Polskie prawo polityczne..., s. 194. 
Postanowienia konwencji górnośląskiej rodziły rozmaite problemy interpretacyjne związane ze wspomnianym brakiem w niej precyzyjnego określenia istoty mniejszości narodowej. Jak w traktacie dotyczącym mniejszości niemieckiej z 28 VI 1919 r., tak i w tym dokumencie nie została zamieszczona definicja tego kluczowego pojęcia. W omawianej konwencji ograniczono się do lakonicznego stwierdzenia, że ,władze nie będą badały, czy ktoś należy lub nie należy do mniejszości narodowej, językowej lub religijnej, ani też nie będą tej przynależności nikomu odmawiały". Na próżno byłoby również szukać w konwencji określenia desygnatów pojęć mogących uchodzić za odpowiedniki terminu „mniejszość narodowa”, czyli określeń „mniejszość językowa”, „mniejszość religijna” czy „mniejszość rasowa”. W dodatku w thumaczeniach tego dokumentu $\mathrm{z}$ oryginału sporządzonego w języku francuskim na języki polski i niemiecki pojawiały się określenia mniejszości przy użyciu różnych przymiotników. Na przykład we wzmiankowanym art. 74 francuskie słowa „minortè de race” (mniejszość rasowa) zostały przełożone na polski jako „mniejszość narodowa”. Z kolei w tekście po niemiecku użyto jeszcze innego pojęcia - „völkische Minderheit”32. Znamienne, że nie padło natomiast określenie „nationale Minderheit”, które wskazywałoby nie tylko na kulturowy, ale również na rasowy kontekst owej zbiorowości. Nie było natomiast żadnych różnic pojęciowych w tekstach konwencji sporządzonych w każdym z tych trzech języków w odniesieniu do dwóch - wydawałoby się jednoznacznych - określeń: „mniejszość językowa” i „mniejszość religijna”. Nawet jednak w tym przypadku nie obeszło się bez wątpliwości interpretacyjnych, nierzadko odpowiednio wykorzystywanych dla celów politycznych. Kwestią sporną mogło się bowiem okazać uznanie za mniejszość językową grupy osób posługujących się zarówno polskim, jak i niemieckim językiem. $\mathrm{Na}$ tej podstawie władze niemieckie na poplebiscytowym terenie Górnego Śląska odmawiały niekiedy uznania osób mówiących także po polsku za mniejszość narodową ${ }^{33}$. Dwujęzycznych mieszkańców tego obszaru, stanowiących ze zrozumiałych historycznie względów niemałą część jego ludności, traktowano po prostu jako grupę stanowiącą integralną część społeczeństwa niemieckiego.

Często pojawiające się wątpliwości co do sposobu interpretacji postanowień konwencji starał się - z różnym zresztą skutkiem - rozwiewać w swej wykładni tego dokumentu prezydent Komisji Mieszanej dla Górnego Śląska, wspomniany już Felix Calonder. Warto przytoczyć zwłaszcza jego pogląd na rodzący wątpliwości art. 74 tego dokumentu. Calonder wyraźnie uznał, że została w nim uregulowana kwestia ,przeprowadzenia linii podziału między ludnością mniejszościową a większościową", a w tym celu przyjęto zasadę,

\footnotetext{
${ }^{32}$ Reichsgesetzblatt, 1922, Bd. 2, Nr 10, s. 278.

${ }^{33}$ Szerzej o tym K. Jonca, Polityka narodowościowa Trzeciej Rzeszy..., s. 217.
} 
że „W sprawie przynależności określonej osoby lub mniejszości jest jedynie miarodajną subiektywna wola zainteresowanej jednostki" ${ }^{34}$. W związku z tym każdemu zamieszkałemu na obszarze poplebiscytowym miało przysługiwać prawo „przejścia od mniejszości ku większości i odwrotnie”. Powyższa opinia prowadziła tego polityka do wniosku, podkreślającego wskazaną wymowę dokonanej przez niego interpretacji, że o przynależności do mniejszości powinna rozstrzygać „każdorazowa wola” osoby zainteresowanej określeniem swego statusu narodowego. Oficjalne stanowisko prezydenta Komisji Mieszanej w sprawie zasad stosowania konwencji z 15 V 1922 r. bynajmniej nie zażegnało sporów wokół jej postanowień. Na ten temat musiał się nawet wypowiedzieć Stały Trybunał Sprawiedliwości Międzynarodowej w Hadze. W swym wyroku z 26 IV 1928 r. zajął on - odnosząc się do sporu w kwestiach szkolnych na obszarze poplebiscytowym - jednoznaczne stanowisko w sprawie kryterium przynależności narodowej. Przyjął mianowicie za podstawę jej określenia subiektywną opcję osoby domagającej się uznania swoich praw w tej dziedzinie. W orzeczeniu tym przychylono się do opinii strony polskiej, która opowiadała się za taką właśnie interpretacją postanowień konwencji górnośląskiej. W wyroku Trybunału czytamy, że

„problem czy osoba należąca do mniejszości - a zatem czy jest ona uprawniona rościć sobie prawo do swobody decydowania, które zawiera układ o ochronie mniejszości - jest stwierdzeniem faktu i jako takie nie jest jedynie kwestią woli. Jeśli deklaracja stojąca w pełnej sprzeczności z faktami nie musi być rozpatrywana stosownie do Konwencji Genewskiej, to z tego bynajmniej nie wynika, że w takim przypadku przestaje być użyteczny zakaz sprawdzania i kwestionowania" ${ }^{95}$.

W związku z tym uznano, że „,deklaracja o przynależności do mniejszości nie może być składana wbrew dobrej wierze", co oznaczało przyjęcie zasady postępowania w tej sprawie ,według własnego sumienia i na osobistą odpowiedzialność". Nawet urzędowa wykładnia Stałego Trybunału Sprawiedliwości Międzynarodowej nie zakończyła jednak sporów wokół postanowień konwencji z 15 V $1922 \mathrm{r}$.

Jeszcze przed wydaniem przez ten sąd odnośnego wyroku niektórymi problemami dotyczącymi mniejszości narodowych zajęła się również Liga

${ }^{34}$ Zbiór urzędowy pogląów Prezydenta Komisji Mieszanej dla Górnego Śląska z dziedziny praw mniejszościowych wydanych na podstawie przepisów części III polsko-niemieckiej Konwencji Genewskiej z dnia 15 maja 1922 r. w czasie od 15 czerwca 1922 do 15 lipca 1937 r., t. 1, Cieszyn 1937, s. 32 .

${ }^{35}$ Publication de la Cour Permanente de Justice Internationale. Seria A, 15. Receuil des Arrets nr 12, J. W., 1928, nr 31/32. Podaję za J. Kostanecki, op. cit., s. 235. Niektórzy autorzy dostrzegali w tym orzeczeniu brak wyraźnej konsekwencji ze strony Trybunału, wynikającej z pewnych niedostatków samej konwencji górnośląskiej. Por. A. Maruszczak, Wadliwość postanowień Konwencji genewskiej w rozstrzygnięciu skarg mniejszościowych, „Przegląd Zachodni”, nr 5/6, 1950, s. 443 i n. 
Narodów. Na jej forum podjęto w 1927 r. kontrowersyjną kwestię znajomości języka niemieckiego na polskim obszarze poplebiscytowym ${ }^{36}$. Przy okazji ożywionej dyskusji na ten temat i wydania stosownej rezolucji wypłynęła sprawa charakteru gwarancji mniejszościom narodowym udzielanych przez Ligę Narodów. Na tym tle doszło nawet do sporu między ministrami spraw zagranicznych Niemiec i Polskim - Gustavem Stresemannem i Augustem Zalewskim. Pierwszy z nich przekonywał, że gwarancje ze strony tej organizacji powinny zostać rozszerzone „w celu podbudowania trwałej, narodowo-kulturalnej autonomii”. W opinii polskiego dyplomaty należało natomiast gwarancje udzielane przez Ligę Narodów traktować tylko jako „przejściowe postanowienia ochronne”, które powinny przede wszystkim przyczynić się do integracji mniejszości narodowych z resztą społeczeństwa. W gruncie rzeczy to właśnie władzom niemieckim zależało na doprowadzeniu do „zlania się” polskiej mniejszości z resztą społeczeństwa, co rodziło krytyczne komentarze ze strony polskich polityków i prawników już w latach 20. i 30 ubiegłego stulecia $^{37}$.Wracając do kwestii gwarancji: ani w konwencji z 15 V 1922 r., ani w innym traktacie w przyjętym po I wojnie światowej nie zostało jednak bliżej sprecyzowane ich pojęcie, choć Rada Ligi Narodów zajęła się tym problemem już pod koniec 1920 r. Nie potrafiła wszakże wypracować jednoznacznego stanowiska w tej sprawie ${ }^{38}$. Mimo to Rada Ligi Narodów nie uchylała się przed użyciem sformułowań mających świadczyć o przyjęciu przez nią gwarancji w odniesieniu do postanowień konwencji górnośląskiej. Tylko w 1922 r. dwukrotnie wzięła na siebie taki obowiązek - w rezolucjach z 16 V i 20 $\mathrm{VII}^{39}$. Również w samej konwencji zostały zamieszczone artykuły, których celem było zapewnienie prawnej ochrony realizacji jej postanowień (art. 55-63, 292-303, 555-556). W tym celu powołano także specjalne organy czuwające nad przestrzeganiem konwencji, a mianowicie Górnośląską Komisję Mieszaną z siedzibą w Katowicach i Górnośląski Trybunał Rozjemczy z siedzibą w Bytomiu. W przypadku naruszenia praw mniejszości przewidziane zostały jeszcze inne środki mające nie dopuścić do takich sytuacji bądź niwelować skutki postępowania niezgodnego z konwencją. Jednym z najważniejszych instrumentów służących ochronie praw mniejszości była możliwość występo-

${ }^{36}$ S. Komar, Górnoślaska Konwencja Genewska pomiędzy Polska a Niemcami 1922-1937 na tle stosunków międzynarodowych, Katowice 1938, s. 41 i n.; G. Kaeckenbeeck, The International Experiment of Upper Silesia, London 1942, s. 324 i in.

${ }^{37}$ Por. M. Grażyński, Z Górnego Śląska, „Przegląd Współczesny”, t. IV, 1923, s. 125; R. Bierzanek, Autonomia narodowościowa, „Sprawy Narodowościowe”, nr 4-5, 1937, s. 368.

${ }^{38}$ S. Kutrzeba, Mniejszosśc w najnowszym prawie międzynarodowym, Lwów-Warszawa-Kraków 1925, s. 62.

${ }^{39}$ K. Kierski, op. cit., s. 62; K. Jonca, Status prawny mniejszości..., s. 33. Stanowisko polskiej doktryny prawnej w sprawach mniejszości zostało już w okresie międzywojennym dość szczegółowo i na ogół obiektywnie omówione w odnośnej literaturze niemieckiej. Por. J. Chodzidlo, Das Minderheitenproblem in der polnischen Rechtsauffassung, Berlin 1937, passim. 
wania przez jej przedstawicieli nawet do samej Ligi Narodów ze skargami na nierespektowanie postanowień konwencji.

Interpretacją konwencji górnośląskiej zajęły się nie tylko międzynarodowe organy powołane do zabezpieczenia jej przestrzegania, ale także nierzadko wybitni reprezentanci ówczesnej nauki prawa w Polsce i Niemczech. Choć formułowane przez nich opinie, wątpliwości i zastrzeżenia nie mogły mieć charakteru urzędowej wykładni, zawierały jednak niemało ciekawych ustaleń dotyczących oceny regulacji statusu prawnego mniejszości narodowych, mogących pośrednio wpływać na realizację postanowień konwencji. Warto zatem przypomnieć poglądy przynajmniej niektórych przedstawicieli doktryny prawnej okresu międzywojennego. Wypowiedzi na ten temat $\mathrm{z}$ reguły koncentrowały się na dwóch podstawowych kwestiach: czym jest mniejszość narodowa i co decyduje o przynależności do niej. Według Zygmunta Cybichowskiego pod pojęciem mniejszości należało rozumieć przede wszystkim mniejszość językową i religijną ${ }^{40}$. Prawa takich właśnie mniejszości powinna - jak dowodził on w 1928 r. - chronić interpretowana przez niego konwencja oraz odnośny traktat z 1919 r. Z kolei dla Kazimierza Kierskiego najważniejszy w pojęciu mniejszości był czynnik etniczny określany przez tego prawnika także jako element rasowy. Jeszcze inaczej do tego problemu ustosunkował się wspomniany autor rozprawy doktorskiej na temat konwencji górnośląskiej - Jerzy Kostanecki. Podobnie jak wzmiankowany już Charles Dupuis opowiadał się on za rozgraniczeniem określeń ,mniejszość językowa”, „mniejszość rasowa” i „mniejszość religijna”, wychodząc z założenia, że każde z nich oznacza coś innego i dopiero łączne ujęcie tych terminów tworzy desygnaty pojęcia mniejszości narodowej. W przekonaniu Kostaneckiego każda $\mathrm{z}$ tych trzech mniejszości zasługiwała jednak w takim samym stopniu na międzynarodową ochronę prawną - właśnie dlatego, że stanowiła mniejszość i z tej racji była „słabiej umocowana” w strukturach zamieszkiwanego przez nią państwa ${ }^{41}$. Myśl o potrzebie rozróżnienia poszczególnych rodzajów mniejszości przewijała się nie tylko w polskiej, ale również w niemieckiej doktrynie prawnej po I wojnie światowej. Erich Flachbarth dowodził w ostatnim roku obowiązywania konwencji górnośląskiej (1937), raczej krytycznie oceniając skutki tego dokumentu, że o ile w dość łatwy sposób można (opierając się na kryterium obiektywnym) wyodrębnić mniejszość językową lub religijną, o tyle znacznie trudniej uczynić to w odniesieniu do mniejszości narodowej. Do tej ostatniej powinno się bowiem zaliczać tych, którzy „nie przyznają się do panującego narodu”, odznaczając się ,szczególnym poczuciem narodowym” odmiennym od ,poczucia członków większości narodu”42.

${ }^{40}$ Z. Cybichowski, Międzynarodowe prawo publiczne i prywatne, Warszawa 1928, s. 237.

${ }^{41}$ J. Kostanecki, op. cit., s. 221.

${ }^{42}$ E. Flachtbarth, System des internationalen Minderheitenrechts, Budapest 1937, s. 134. Jeszcze przed tym prawnikiem opinię o potrzebie uwzględniania czynnika narodowego w odniesieniu 
Flachtbarth nie potrafił jednak precyzyjnie określić kryterium przynależności do tak rozumianej mniejszości. Ciekawe spojrzenie na problem mniejszości zaproponował w 1929 r. ceniony prawnik niemiecki Carl G. Bruns. Trafnie zwrócił on bowiem uwagę na nieporuszaną przez innych znawców prawa międzynarodowego kwestię nieprzyznania przez traktaty międzynarodowe mniejszościom osobowości prawnej, co rodziło - jego zdaniem - rozmaite konsekwencje $\mathrm{w}$ dziedzinie funkcjonowania tych zbiorowości. W dodatku Bruns uznał pojęcie „mniejszość” nie za termin stricte prawniczy, lecz przede wszystkim za określenie socjologiczne, którego desygnaty obejmowały zarówno obywateli, jak i nieobywateli danego państwa ${ }^{43}$.

Jak już wzmiankowałem, przedmiotem analiz podejmowanych przez polskich i niemieckich prawników była również kwestia kryteriów przynależności do mniejszości narodowej. W tej ważnej sprawie możliwe do przyjęcia okazały się dwa odmienne stanowiska naukowe. Pierwsze z nich opierało się na zastosowaniu obiektywnych przesłanek przynależności do mniejszości, czyli na uznaniu za jej kryterium wspólnego języka, religii, tradycji czy kultury, co znalazło zresztą odbicie w konwencji górnośląskiej, zapewne nie ułatwiając wdrażania jej postanowień. Druga opcja zakładała, że o przynależności do mniejszości powinny decydować czynniki subiektywne, a zatem przede wszystkim dobrowolny i świadomy akt woli jednostki. Ku takiej interpretacji skłaniał się Stały Trybunał Sprawiedliwości Międzynarodowej w Hadze, choć nie zawsze zajmował konsekwentne stanowisko w sprawie określenia przesłanek przynależności do mniejszości, jak np. w wyroku z $26 \mathrm{~V} 1926$ r. $^{44}$ Należy zauważyć, że za przyjęciem obiektywnego kryterium opowiadało się niewielu prawników, obawiając się skutków związanych z nim rozmaitych uwarunkowań politycznych (możliwość wpływania przez władze państwowe na ustalenia dotyczące używania określonego języka czy wyznawania określonej religii $\mathrm{i}$ in.). Wśród polskich znawców prawa międzynarodowego zwolennikami teorii obiektywnej byli w zasadzie tylko Kierski oraz Władysław Zaleskit5. Również w Niemczech - przede wszystkim w okresie Republiki Weimarskiej - sporadycznie reprezentowano pogląd o celowości stosowania kryterium języka, religii czy kultury jako podstawy określającej przynależ-

do mniejszości wyraził polski autor S. Stebelski w artykule Mniejszość a emigracja, „Polacy Zagranicą", 1/1930, s. $110 \mathrm{i} \mathrm{n.}$

${ }^{43}$ C.G. Bruns, Grundlagen und Entwicklung des internationalen Minderheitenrechts, Berlin 1929, s. 22.

${ }^{44}$ Wyrażono w nim pogląd, że „Z prawa mniejszościowego może korzystać tylko ten, kto do jakiejś mniejszości należy”, co w opinii C.G. Brunsa (Grundlagen und Entwicklung..., s. 32) oznaczało, że Trybunał skłonił się ,raczej ku obiektywnej teorii”.

${ }^{45}$ K. Kierski, op. cit., s. 269; W. Zaleski, op. cit., s. 13. Wśród niepolskich i nieniemieckich autorów do przyjęcia koncepcji obiektywnych kryteriów przynależności do mniejszości narodowej skłaniał się wtedy m.in. J.F. Duparc w pracy La protection de minorités, de race, de langue et de religion, Paris 1922, s. 31. 
ność do mniejszości narodowej. Współczesny badacz tej problematyki, Karol Jonca, wymienia tylko jednego rzecznika takiego stanowiska w okresie przed objęciem władzy przez nazistów, a mianowicie wiceprezydenta prowincji górnośląskiej Paula Fischera ${ }^{46}$. W polskiej (aż do 1937 r.) i niemieckiej doktrynie prawnej (w zasadzie tylko do 1933 r.) tworzonej w okresie obowiązywania konwencji genewskiej dominująca okazała się teoria subiektywna. Za jej rzeczników można - choć w różnym stopniu - uznać niemal wszystkich już wymienionych przeze mnie uczonych. Znamienne, że postulat stosowania subiektywnych kryteriów w odniesieniu do mniejszości narodowej bardziej przyjął się w nauce niemieckiej (głównie jednak w okresie Republiki Weimarskiej) niż w polskim piśmiennictwie prawniczym. Odpowiadał on bowiem polityce władz Rzeszy, zmierzającej do doprowadzenia do integracji mniejszości polskiej z resztą społeczeństwa, czyli do jej stopniowego zaniku ${ }^{47}$. Prócz Brunsa czy również omówionego Hermanna Plettnera indywidualny akt woli uznał już w 1924 r. za najważniejsze kryterium przynależności do mniejszości adwokat Udo Rukser ${ }^{48}$. W podobny sposób o przydatności teorii subiektywnej wypowiedział się kilka lat później Paulus von Husen Warderholt. Będąc przedstawicielem rządu niemieckiego w Komisji Mieszanej dla Górnego Śląska, starał się on wykazać, że w warunkach zmian cywilizacyjnych po I wojnie światowej posługiwanie się teorią obiektywną zamiast - w jego opinii - lepszą od niej koncepcją subiektywną stanowiłoby „pozostałość pozytywistycznych błędów XIX wieku"49.

Po ustanowieniu w Rzeszy rządów nazistowskich pod koniec stycznia 1933 r. pojawiły się nowe okoliczności polityczne mające wpływ na stosowanie i interpretację konwencji górnośląskiej. Choć nadal formalnie obowiązywała ona w hitlerowskich Niemczech - podobnie jak w Polsce - aż do swego wygaśnięcia w 1937 r., to jednak zmianie na jeszcze bardziej krytyczne niż w okresie Republiki Weimarskiej uległo podejście do niej tak ze strony

${ }^{46}$ K. Jonca, Polityka narodowościowa Trzeciej Rzeszy..., s. 220. P. Fischer wyłożył swoje poglądy w powołanej już pracy Das Recht und der Schutz der polnischen Minderheit in Oberschlesien, Berlin 1931.

${ }^{47}$ Niemieccy autorzy prac na ten temat nie kryli zresztą takiego zamiaru, wskazując wprost na potrzebę asymilacji polskiej mniejszości z ludnością niemiecką. Por. H. Gerber, Kulturautonomie als Eigenart minderheitenrechtlicher Ordnung und ihre Verwirklichung nach der ethnischen Verfassung, Berlin 1926, s. 37 i n.; C.G. Bruns, Gesammelte Schriften zur Minderheitenfrage, Berlin 1933, s. 29.

${ }^{48}$ U. Rukser, Zum Begriff der Minderheit im Sinne des Völkerrechts, „Juristische Wochenschrift", H. 17-18, 1924, s. 1298. Por. też E. Warschauer, Rechtsgrundsätze zum Minderheitenschutze des deutsch-polnischen Abkommens über Oberschlesien vom 15. Mai 1922, „Juristische Wochenschrift", H. 17-18, 1924, s. 1300.

49 J. Waderholt, op. cit., s. 15 i n. 
władz Trzeciej Rzeszy, jak i tamtejszej doktryny prawnej. W nowych warunkach ustrojowych w Niemczech, opartych na zasadzie wodzostwa prowadzącej ku totalitaryzmowi, wyłoniły się dwie fundamentalne kwestie, które pozostawały w związku z postanowieniami konwencji górnośląskiej: sprawa konfrontacji z nią tworzonego od 1933 r. w ramach tzw. procesu ujednolicania (Gleichschaltung) życia publicznego narodowosocjalistycznego systemu prawnego oraz problem objęcia nią dyskryminowanej w Trzeciej Rzeszy ludności żydowskiej mieszkającej na obszarze poplebiscytowym. Jak słusznie zauważył Karol Jonca, „wersalsko-genewska ochrona mniejszości” nie mieściła się w nazistowskich koncepcjach wspólnoty narodowej (Volksgemeinschaft) stanowiącej naczelną kategorię nacjonalistycznego i rasistowskiego światopoglądu Adolfa Hitlera i innych prominentów Trzeciej Rzeszy ${ }^{50}$. Przyjęte po I wojnie międzynarodowe traktaty w sprawach mniejszości uważane były przez władze nazistowskie za przejaw odrzucanych w państwie Hitlera liberalnych zasad równości praw i obowiązków wszystkich obywateli. Do ich sformułowania mieli już w XIX w. - jak głosiła propaganda w Trzeciej Rzeszy - przyczynić się żydowscy intelektualiści w celu zapewnienia swoim współrodakom rozsianym po całym świecie możliwości asymilacji z resztą społeczeństwa i oddziaływania na sprawy państwowe ${ }^{51}$. Nazistowska doktryna prawna negowała nawet samo pojęcie „mniejszość narodowa” i związane $\mathrm{z}$ nim problemy polityczno-prawne, przeciwstawiając tym zagadnieniom własną teorię narodowości. W zasadzie uwzględniała ona jedynie interesy czystych rasowo Niemców, nie troszcząc się w ogóle o innych mieszkańców Rzeszy, którym niekiedy - jak w przypadku Żydów - odmawiano nawet prawa obywatelstwa. Przypomnę, że nie tylko wobec nich, ale także np. wobec Polaków nierzadko stosowano jeszcze inne, rozmaite restrykcje i represje.

Kierując się takimi przesłankami ideowymi, wrocławski profesor prawa międzynarodowego i zagorzały nazista Gustav Walz wystąpił już w 1934 r. oraz w późniejszym okresie z koncepcją nowej regulacji spraw narodowościowych. Opierała się ona na założeniu, że każdej grupie narodowej należy zagwarantować „w państwie kierowanym przez inną narodowość (Volkstum) elementarne prawo do własnego porządku narodowo-kulturalnego" ${ }^{52}$. W ten sposób liberalna koncepcja przewidująca ochronę subiektywnego prawa poszczególnych jednostek należących do mniejszości do posługiwania sie własnym językiem czy wyznawania własnej religii zostałaby zastąpiona przez

${ }^{50}$ K. Jonca, Trzecia Rzesza wobec problemu ochrony mniejszości narodowych 1933-1941, (w:) Rola mniejszości niemieckiej 1918-1945, cz. 3: Hitlerowskie „rozwiazanie” problemu mniejszości niemieckiej, pod red. A. Czubińskiego, Poznań 1986, s. 407.

${ }^{51} \mathrm{~W}$ ten sposób interpretował genezę traktatów mniejszościowych zawartych po I wojnie światowej nawet krytycznie nastawiony do nazizmu C.G. Bruns (Gesammelte Schriften ..., s. 33), nie mówiąc o niemieckich prawnikach (m.in. G. Walz) oficjalnie reprezentujacych narodowosocjalistyczny światopogląd.

${ }^{52}$ G. Walz, Volkstum, Recht und Staat, Breslau 1937, s. 32. 
,jedynie słuszne i sprawiedliwe" prawo do zachowania narodowej tożsamości, wynikającej z tradycji i historii, przez całą grupę osób o wspólnym pochodzeniu. Wskutek respektowania tego założenia niemożliwa byłaby zwłaszcza przymusowa asymilacja odrębnych grup narodowych z resztą społeczeństwa. $\mathrm{Na}$ tym miała polegać istota sformułowanego przez Walza „prawa o grupach narodowych" (Volksgruppenrecht) ${ }^{53}$. Z podbudowanej elementami rasizmu i antysemityzmu koncepcji tego prawnika jednoznacznie wynikało, że Żydzi nie stanowili tak rozumianej grupy i że nie mogli oni uważać się za przynależnych do narodu niemieckiego. Jak wiadomo, zostali oni objęci w Trzeciej Rzeszy odrębnym prawodawstwem rasistowskim, które do 1937 r. nie obowiązywało jednak na obszarze poplebiscytowym. Konwencja górnośląska traktowała bowiem - o czym wzmiankowałem - Żydów zamieszkałych na tym terytorium jako mniejszość podlegającą ochronie prawno-międzynarodowej. Walz starał się w związku z tym podważyć zasadność obowiązywania tej konwencji, wskazując jako uzasadnienie swego stanowiska na prymat wewnątrzniemieckich regulacji prawnych nad normami ,wersalsko-genewskiego porządku" 54 . Władze nazistowskie nie odważyły się jednak w okresie obowiązywania konwencji górnośląskiej na jej oficjalne odrzucenie. Nierzadko zdarzały się natomiast przypadki naruszania postanowień konwencji ${ }^{55}$. Co się tyczy doktryny opracowanej przez Walza: jej analiza prowadzi do jeszcze jednego ważnego wniosku z punktu widzenia spraw narodowych. Wrocławski prawnik mianowicie nie ukrywał, że jego poglądy służyły przede wszystkim interesom niemieckiej mniejszości poza granicami Rzeszy. Jakikolwiek ,atak na cząstkę niemieckiej narodowości” lub próby jej „brutalnego wynarodowienia" powinny być traktowane jako naruszenie pokoju w stosunkach międzynarodowych, a nawet jako przejaw agresji na Rzeszę. Przeciwko ewentualnej asymilacji bądź wynarodowieniu grup narodowych występował w swych publikacjach inny ceniony przez pewien okres w Trzeciej Rzeszy profesor prawa, Carl Schmitt. Jak Walz, tak i on opowiadał się za objęciem przez prawo obowiązujące w hitlerowskich Niemczech wszystkich Niemców mieszkających także poza granicami Rzeszy ${ }^{56}$.

${ }^{53}$ Ibidem, s. 33. Por. też idem, Nationalsozialismus und Völkerrecht, ,,Völkerbund und Völkerrecht", H. 9, 1934, s. 76; idem, Neue Grundlagen des Volksgruppenrechts. Politische Wissenschaft, Berlin-Leipzig-Wien 1940, s. 79.

${ }^{54}$ G. Walz, Die völkerrechtliche Lage Oberschlesiens, „Zeitschrift der Akademie für Deutsches Recht”, H. 5, 1937, s. 67 i n.

${ }^{55}$ Szerzej o tym por. K. Jonca, Polityka narodowościowa Trzeciej Rzeszy..., s. 242 i n. Por. też m.in. W. Wrzesiński, Wygaśnięcie Konwencji Genewskiej w sprawie Górnego Śląska, (w:) Między Królewcem, Warszawa, Berlinem a Londynem. Studia i szkice z dziejów XX wieku, pod red. W. Wrzesińskiego, Toruń 2001, s. 23 i n.

${ }^{56}$ Por. C. Schmitt, Der neue Raumbegriff in der Rechtswissenschaft, Raumforschung und Raumordnung, Heidelberg 1940; idem, Völkerrechtliche Großraumordnung, Berlin-Leipzig-Wien 1941. 
Wraz z wygaśnięciem w 1937 r. konwencji górnośląskiej sytuacja prawna mniejszości narodowych na obszarze poplebiscytowym uległa radykalnemu pogorszeniu. W pierwszym rzędzie ucierpieli na tym tamtejsi Żydzi, których już bez żadnych ograniczeń poddano prawodawstwu rasistowskiemu ${ }^{57}$. W nie tak drastyczny sposób władze nazistowskie obeszły się z ludnością polską, ale również $\mathrm{w}$ odniesieniu do niej stosowano rozmaite przejawy dyskryminacji, choć do początku 1939 r. Hitler starał się układać poprawne stosunki z Polską. Jeszcze w listopadzie 1937 r. deklarował on poszanowanie praw mniejszości polskiej, zapewniając o nieczynieniu żadnych przeszkód w ,ujawnianiu tej przynależności". Wbrew enuncjacjom oficjalnej propagandy nazistowskiej o respektowaniu praw mniejszości polskiej działacz Związku Polaków w Niemczech Stefan Kaczmarek (piszący pod pseudonimem Emil Kuroński) stwierdził w 1938 r., że ,obecna sytuacja prawna w Niemczech sprawia, że ludność polska faktycznie znajduje się poza prawem i jest przedmiotem samowoli administracji i czynników rządzącej partii" ${ }^{58}$. Niewątpliwie sytuacja Polaków w Niemczech - tak na byłym obszarze plebiscytowym, jak i poza nim - stała się jeszcze trudniejsza i bardziej niebezpieczna po wybuchu II wojny światowej.

W zakończeniu należy skonstatować, że konwencja genewska z 1922 r. oraz wcześniejszy traktat mniejszościowy (obowiązujący także po 1937 r.) stworzyły na ogół skuteczne przesłanki prawnej ochrony mniejszości na Górnym Śląsku, umożliwiając Polakom, Niemcom czy Żydom dbałość o własną tożsamość i rozwój narodowy. Oceniając z tego punktu widzenia odnośne regulacje prawne, można generalnie uznać, że spełniły one przynajmniej niektóre oczekiwania związane z budową pokojowego ładu międzynarodowego po I wojnie światowej. W wyniku przestrzegania przez Niemcy i Polskę wprawdzie nie zawsze konsekwentnego i w różnym stopniu przez władze obu państw - postanowień konwencji z 1922 r. na kilkanaście lat odsunięta została na Górnym Śląsku groźba wybuchu ostrych konfliktów narodowościowych.

57 Już w czerwcu 1937 r. została w Niemczech przyjęta, wymierzona głównie w Żydów, ustawa „o środkach, jakie należy zastosować na byłym obszarze plebiscytowym wskutek wygaśnięcia Konwencji”. F. Połomski, Ustawodawstwo rasistowskie III Rzeszy i jego stosowanie na Górnym Ślasku, Katowice 1970, s. 103.

${ }^{58}$ E. Kuroński, Położenie prawne ludności polskiej w Trzeciej Rzeszy, Katowice 1938, s. 57. Podobną opinię wyraził działacz polski na Górnym Śląsku, A. Bożek, przestrzegając przed poważnym traktowaniem deklaracji władz nazistowskich o gotowości respektowania praw mniejszości. R. Hajduk, Arka Bożek, Katowice 1963, s. 47. 


\section{LEGAL ASPECTS OF THE SITUATION OF ETHNIC MINORITIES IN UPPER SILESIA IN 1918-1939}

\section{Summary}

This paper discusses the legal situation of German and Polish ethnic minorities in Upper Silesia, which was divided between Germany and Poland in the wake of uprisings (1919-1921) and the plebiscite of March 1921. The discussion concentrates on the provisions of the Upper Silesia Convention (known also as the Geneva Convention) concluded by the German Reich and the Republic of Poland for fifteen years under the auspices of the League of Nations in May 1922. Emphasis is laid on the main provisions, including the so-called fundamental rights of minorities (Art. 64-68), which were meant to ensure equal treatment and free development in the spheres of language, education, religion, etc. to ethnic minorities.

The discussion also touches upon other issues - which were not fully regulated by the Convention - concerning the interpretation of the term 'ethnic minority' at the League of Nations and other organisations and institutions (Inter-Allied Mixed Commission for Upper Silesia), as well as in the prevailing legal opinions in Germany and Poland at that time. On the example of the views of such jurists as Bruns, Flachtbarth, Walz, Cybichowski, Kierski and Kostanecki, arguments and controversies are shown which surrounded the criteria for defining ethnic minorities. Over this matter two views clashed. The first and more popular held a person to be member of an ethnic minority if he or she expressed their bona fide will to be counted as one (subjective criterion). The second was based on the assumption of objective membership in an ethnic minority (criteria of language, religion, culture and tradition). In the author's opinion, the Upper Silesia Convention contributed to the reduction of ethnic tensions in the area where it was enforced.

\section{LES ASPECTS JURIDIQUES DE LA SITUATION DES MINORITÉS NATIONALES EN HAUTE SILÉSIE, 1918-1939}

\section{Résumé}

L'objet de l'article est la situation juridique des minorités nationales allemande et polonaise sur le territoire de la Haute Silésie, divisé entre l'Allemagne et la Pologne, suite aux insurrections (1919-1921) et au plébiscite du mars 1921. L'auteur de l'article se concentre sur les décisions de la convention relative à la Haute Silésie (appelée également convention de Genève), conclue pour une durée de quinze ans, sous les auspices de la Société des Nations par le Reich allemand et la République de Pologne en mai 1922. L'article fait l'analyse non seulement des dispositions principales de la convention, dont celle des droits essentiels des minorités (art. 64-68) qui devai- 
ent garantir aux minorités nationales l'égalité du traitement et liberté du développement en matière de la langue, de l'enseignement, de la religion, etc., mais l'objet des réflexions constituent également les questions non réglées dans leur intégralité par la convention, concernant l'interprétation de la notion «minorité nationale» par les membres de la Société des Nations et d'autres organisations et institutions (Commission Mixte Interalliée pour la Haute Silésie, entre autres), mais également par la doctrine juridique de l'époque en Allemagne et en Pologne. Sur la base des idées, comme celles des juristes savants tels que C. Bruns, E. Flachtbarth, G. Walz, Z. Cybichowski, K. Kierski et J. Kostanecki entre autres, ont pu être décrits les différends et les controverses se référant notamment aux critères de distinction des minorités nationales. Concernant cette question, deux positions s'affrontent. La première, plus populaire, admet que la base permettant de reconnaître quelqu'un comme le membre d'une minorité est sa volonté individuelle, exprimée de bonne foi (critère subjectif). La deuxième position se base par contre sur le principe d'appartenance objective à une minorité nationale (critère de langue, de religion, de culture et de tradition).

L'auteur du présent article est convaincu que la convention de la Haute Silésie a pu contribuer à la limitation des tensions nationales sur le territoire de son application. 